\title{
Symeon the New Theologian's Hymns of Divine Eros: A Neglected Masterpiece of the Christian Mystical Tradition
}

\author{
JOHN McGUCKIN
}

$\overbrace{h}$ he Byzantine saint and poet Symeon the New Theologian $(949-1022)^{1}$ is one of the Christian world's greatest mystics, if such a term can properly be used of ancient writers. It is here applied for the sake of convenience, and for the purpose of unveiling the author, as it were, who is not only a visionary of the highest order within the Eastern Orthodox tradition, but equally one of the Christian world's most lyrical and rhapsodic writers. It is a startling fact that it is only in recent years that his works have become available in English translation, and a sadder one that his name is still largely unknown to a wider public who would otherwise undoubtedly be interested in a spirituality suffused with light and hope and one of the most profound senses of the mercy and compassion of God. The situation of neglect is comparable to finding something of the quality of the works of San Juan de la Cruz still awaiting an edition. The commentator is torn between excitement at the possibility of revealing "new" literary and theological treasures, and wonder at how large the task is to contextualize the deep traditions of medieval Greek (Byzantine) spirituality in an environment of western Church history and theology within which spirituality at large has frequently been marginalised or exiled, and from which even a rudimentary awareness of Greek medieval literature has customarily been missing. It is partly to fulfill that task of reintroduction that the present essay sets out to give a brief background history of this medieval poet, monk, and controversialist, and then to introduce aspects of one of his most extraordinary works, the Hymns of Divine Eros. ${ }^{2}$ In this remarkable figure we find combined the vocations of radical prophet and ecstatic visionary: of poet and soul-friend. His work brings to the fore the pressing need for the Christian Church to theologize primarily from its living experience of God: the need for each believer to accept the highest vocation as "friend of God," and prophet of the presence of God.

\section{SYMEON THE NEW THEOLOGIAN: LIFE AND TIMES ${ }^{3}$}

Symeon was born in 949 to a wealthy family of provincial aristocrats in Asia Minor. It is possible that, in accordance with the customs of the day, he was 
castrated as an infant for future service in the imperial palace at Constantinople, where many of the higher offices were reserved for noble eunuchs. ${ }^{4}$ As an adult he laments how he never found in his family the "tenderness that nature should have provided." ${ }^{5}$ In places he calls his flight from them into the monastic state as a veritable exodus from Pharaoh's Egypt. ${ }^{6}$ In 960 his father brought him to Constantinople to settle him in his uncle's care, so that the child could be educated and "placed" for a court career. This was at a time of great political instability, and only three years after the young Symeon began his studies a major coup overthrew the government and the general Nicephoros Phocas seized the throne. Symeon's uncle was assassinated during the $\operatorname{coup}^{7}$ and the child's life was briefly thrown in turmoil. Soon after this setback Symeon resurfaced once more in an elevated social setting. An unknown Senator took him onto his household staff. We are told that Symeon attended the Emperor's palace daily, and soon rose through the civil service to the rank of senator himself.

In his twenties he described himself as a rather rakish youth, travelling to and from court on business. ${ }^{8}$ He first encountered the monk Symeon Eulabes ${ }^{9}$ at this time, who was an unusual character attached to the great Stoudium monastery near the walls of Constantinople, and he seems to have joined in the wider group of aristocrats who formed the circle of this odd but generously charismatic figure, who functioned as their father-confessor. Symeon visited Eulabes whenever he was in the city, and the monk gave him spiritual books to read, but clearly there was little more to the connection until the occasion, around 969, when he had an experience that he described (much later) as highly significant for him.

He tells us of a vision of lights one evening as he was saying his night prayers in his chambers: a radiance that filled the room, taking away his sense of space and time, and eventually resolving as one powerful light in the presence of another even brighter radiance. He interpreted the event as his consciousness of his spiritual father interceding for him before Christ. ${ }^{10}$ From that time on the notion of mediation-how the saints can carry others into the presence of God-is central to his thought. It comes out in a variety of images, such as the notion of the Church as a golden chain, whose links are the saints in each generation, ${ }^{11}$ those spirit-bearers (pneumatophoroi) who pass on the kerygma of salvation to each generation, not merely as a preached message, but as the only form in which God transmits charism from one soul to another, that is as the lived experience of love, and the "sensible" 12 awareness of the presence of the Holy Spirit. In his writings there are several other accounts of luminous visions over the course of his life, each of them in their own way remarkable, and little studied. They have in common the sense of a geographical and temporal transcendence, the enfolding in luminous grace, and the feeling of "sweet peacefulness" in the presence of God. Symeon's disciples ${ }^{13}$ 
later spoke of him being accustomed to seeing the light of the Spirit descend on the Eucharistic gifts during the divine liturgy, ${ }^{14}$ and even of emitting light himself during his priestly service.

After his first vision of light as a layman, however, nothing much seems to have changed in the outward circumstances of his life. But it would certainly be a decisive event in retrospect, especially after he left the political service to enter a second life as a monastic. Seven years after his vision, in 976, when he was 27 years of age, another palace coup initiated a sequence of events that changed his life permanently. The imperial Chief Administrator Basil seized the throne on behalf of the young prince (Basil II) who was then in his minority, and Symeon's family seem to have been clearly marked out by the new administration as a hostile element. His political career was definitively terminated at this point, and he seems to have taken temporary refuge with his spiritual father at the Stoudite monastery. At this juncture he tells us that once again he experienced an overwhelming vision of light. ${ }^{15}$ This time we are meant to understand that he saw the radiance of Christ directly, and this became for him a definitive conversion point. It marked his permanent entrance into the monastic state. In another place I have drawn the connection between the visions of light, the timing of the political crises of his era, and the notion of repentance and "change of lifestyle" (from lay aristocrat to monastic leader) which to the medieval Byzantines would have been seen as a naturally interconnected nexus. ${ }^{16}$ In some senses, Symeon is like a Francis of Assisi, or Ignatius of Loyola after him: his metanoia is preceded by traumatic events, and his entrance into the monastic world (where he soon rose to prominence, and exercised a powerful leadership comparable to his status in imperial service) was one where he came into the Church with little theological or ecclesiastical preparation. It is precisely this fresh start that allows his religious voice, when it begins to be heard through his writings as an abbot, to be so distinctive and remarkable. His theology was also apologetic and controversial from the beginning. The more the religious establishment tried to dismiss him as a crank, and as an inexperienced and uneducated man, the more strongly he took his stand on the two principles that shine through all his work: the primacy of direct spiritual experience over book-learning, and the inalienable right of the Spirit-filled to speak with authority to the Church at large, regardless of social or ecclesiastical rank. This of course would make him many enemies, and cause him endless trouble.

In a very short time after his entrance to the Stoudium, Symeon was moved out to the small adjacent St. Mamas monastery. His hagiographer, Stethatos, and those following him too trustingly (for the Vita is tendentious and sometime confused over details), have seen this as an "expulsion" caused by jealousy over his zeal. ${ }^{17} \mathrm{I}$ believe it ought to be read, rather, as his promo- 
tion and his permanent protection by sympathetic patrons outside the court, once his family realized that they could not persuade him to resume political life..$^{18}$ At St. Mamas he found a safe shelter, and was soon to rise even higher. Within three years, in 979-80, Symeon was elected abbot (bigoumen) of the same household, and ordained priest. This rapid promotion indicated the significant patronage he could still bring to bear as a powerful aristocratic leader, even though he was now a monk.

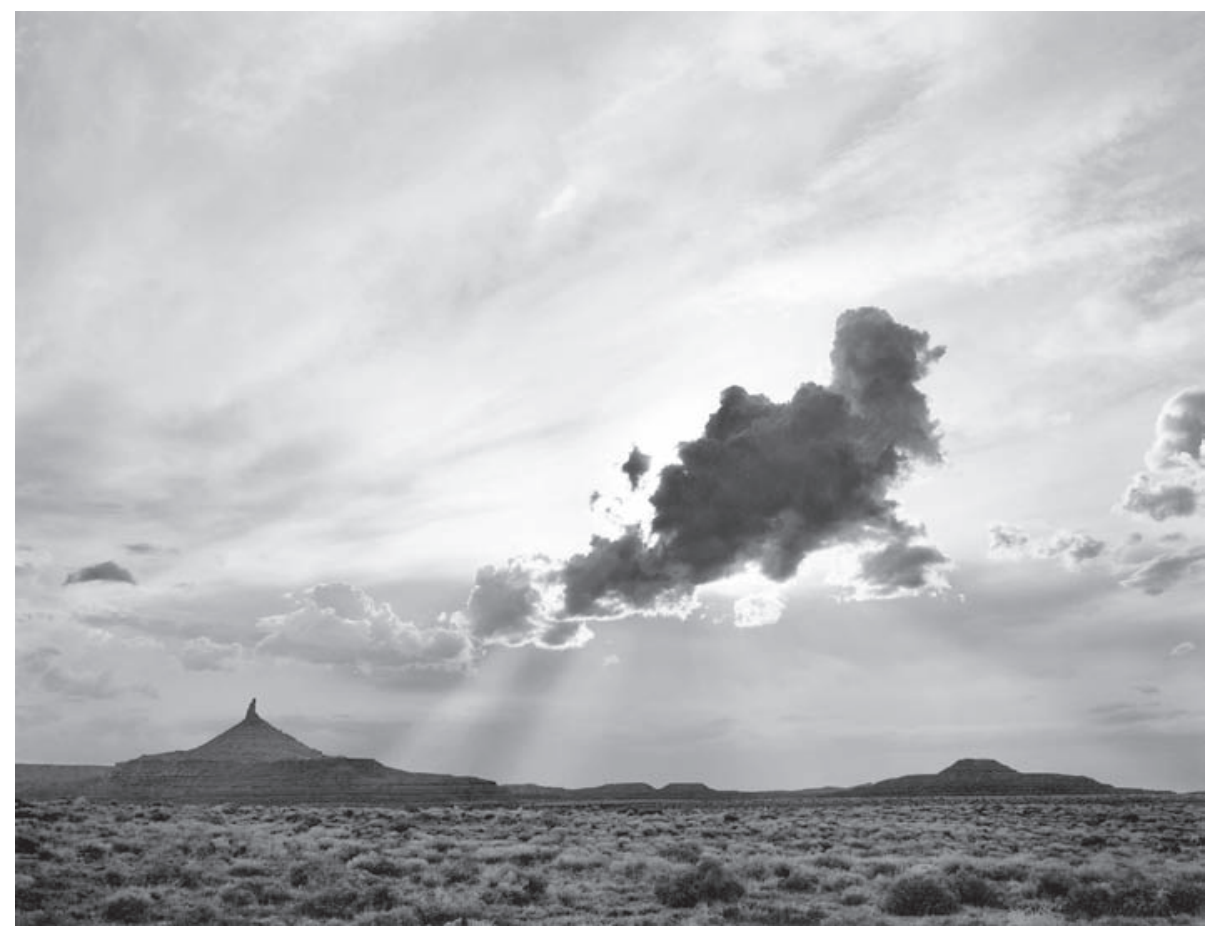

Six-Shooter Peak and Cloud, 1978. (C) Lynn Radeka.

Symeon substantially refurbished the site of St. Mamas, presumably from his own fortune, acting as a renovating ktitor, or founder, a role he assumed which also allowed him extensive rights to reorder the monastic typikon. ${ }^{19}$ At this time he began to deliver the traditional morning instructions, or Catecheses, to the monks of the community, which have survived as the central body of his work. ${ }^{20}$ Much of his approach in the Catecheses, where he explains the monastic lifestyle to his community, is a simple re-statement of standard and traditional Stoudite lore (as might be expected from someone who has only been a monk for three years himself), but he has his own style and emphases, and so he places a particularly strong stress on the dedicated obedience which he expects should be given to the spiritual father by all monks. He stressed the necessity for direct personal experience in the life of the Spirit, underlining the need for regular tears as a sign of the action of the Spirit within the heart of a true 
believer, even insisting that without tears a monk should never approach the sacrament of the Eucharist. His highly emotive approach (his keyword in his spiritual doctrine is the adverb aisthetos- "sensibly" or "with feeling") and his telescoping of the roles of spiritual father-counselor and authoritative Higoumen, and perhaps also his introduction of a vegetarian regimen along with other quirky ideas for inculcating humility in the monks seems to have caused no little conflict among his subordinates.

Sometime around 986-7 Symeon Eulabes died at the Stoudium monastery leaving Symeon as the new head and leader of his school of disciples, a circle that included both monastics and lay aristocrats. ${ }^{21} \mathrm{~A}$ few years later, between 995 and 998, the growing opposition to Symeon's discipline and teaching at St. Mamas broke out in the form of a revolt by "thirty or so of his monks." The biographer tries to pass this off as a small number of discontented malingerers, but thirty was a sizeable body of monks anywhere for that period, and it must have represented the majority of his community. ${ }^{22}$ They threatened him at morning service and lodged an official complaint against him at the patriarchal court, a plea which was dismissed in the abbot's favour. Although the Vita attempts to minimize the whole affair, its usual procedure when dealing with any aspect of the (large) degree of controversy that attended Symeon's life, nevertheless the uprising possibly coincided with the death of Patriarch Nicholas Chrysoberges and the installation of the first patriarchal appointment of Emperor Basil II ruling in his own right, Patriarch Sisinnios II (995-998). ${ }^{23}$ Sisinnios was succeeded by Sergios II Manuelites (999-1019) and the latter's court also instituted legal proceedings against Symeon. These processes were more vigorously pursued and eventually would result in his exile. The first formal arraignment turned around the issue of the unofficial cult of the master which Symeon had instituted in memory of his teacher. The elder's reputation was attacked, in an attempt to discredit the younger Symeon, and after 995 the cult of Symeon Eulabes (consisting in the veneration of his icon, which was more or less a declaration of canonisation independently made from the Patriarchal synod) was forbidden at St. Mamas. The Emperor thus began to move against the younger Symeon by means of the ecclesiastical court process, chiefly employing his long-time confidant Bishop Stephen of Alexina, the patriarchal Chancellor, who from this time onwards became Symeon's relentless opponent.

In 1003 an attempt was made to entangle Symeon in a more formal theological debate concerning his Trinitarian orthodoxy. ${ }^{24}$ He returned a satisfactory answer to the charges but also took the opportunity to lambaste Stephen ${ }^{25}$ (whom he always refers to as a simple monk) for attempting to theologize without first having experienced the stature of "living saint" which the ancient theologians had taught was necessary before one could legitimately 
theologize. ${ }^{26}$ For Symeon this did not just mean a bourgeois piety, but rather the achievement of the highest virtues of sanctity: the acquisition of impassibility (apatheia) and the vision of the divine light. It was tantamount to a declaration of war, as everyone recognized in Stephen of Alexina a model of a courtly (and portly) bishop, not an ascetic hero. The war of attrition carried on for six years in all, mainly by means of letters and treatises and hymns (at this period he began his Hymns of Divine Eros) and it culminated in the ecclesiastical sentence of deposition issued against Symeon in 1005, one that was endorsed by the imperial palace which placed him under house arrest, as a prelude to life-long exile.

On January 3, 1009, Symeon's property was confiscated and he was forcibly exiled to Paloukiton, near Chrysopolis. It was not far away from the capital but far enough over the Bosphorus Straits to matter, and allowed no hope of ever returning to the city. His circle of lay supporters ${ }^{27}$ soon supplied the money (whether consisting of new funds or old ones recycled it is not known) to buy the oratory of St. Marina at Paloukiton, and some nearby lands. And so, re-established in another monastery of his own, Symeon continued to write, and was joined there by a close and loyal band of followers. It was a period that saw the production of some of his most beautiful works, including the majority of the exquisite Hymns of Divine Eros, which are a classic of Byzantine religious writing. In 1022, coming back home from a long journey, he contracted dysentery and died at the age of seventy three. More than thirty years after his death, the Stoudite Abbot Niketas Stethatos was involved in developing a popular city pilgrimage to Symeon's tomb at Chrysopolis, and composing a new "office" for the occasion, and writing the Vita to prepare for the reception of Symeon's relics back into Constantinople. He had to smooth down a lot of controversy still attendant on Symeon's memory. To this end he prepared a Vita celebrating the life and miracles of the saint, collated the writings, ${ }^{28}$ including a collection of $58 \mathrm{Hymns},{ }^{29}$ and disseminated icons suitable for a public cult.

In the years afterwards, Symeon remained a relatively obscure Byzantine saint. Though his memory was kept alive by those who valued teachers of the mystical life, and above all on Mount Athos where, with his stress on the need to see the divine light, and feel the action of the Holy Spirit in the heart with perceptible sensations, he was regarded as a kind of fore-runner of the fourteenth century Hesychast movement. A treatise attributed to Symeon in later years, which outlined a method of prayer posture, and described the correct control of breathing while reciting the Jesus Prayer, made his name especially popular on Athos. ${ }^{30}$ But it is really only in the twentieth century that his name and teachings have become more widely available ${ }^{31}$ to a larger readership, and it can be increasingly seen just how remarkable and original his vision was. ${ }^{32}$ 
His combination of a stress on the light-filled radiance of the divine vision, with a need for the conscious awareness of the Holy Spirit, marks him out as a synthesizer of two great currents of spiritual thought that were then current in eleventh century Byzantium: the spirituality of light that flowed through the Origenian school as interpreted by Gregory of Nazianzus, Diadochus of Photike, and other "Philokalic" authors, and the Syrian school which emphasised the sensibility (aisthesis) of the Spirit in the heart, a school that had many exponents, notably Pseudo-Macarius, Gregory of Nyssa, and Isaac of Niniveh. In his Hymns of Divine Eros Symeon is one of the first successfully to synthesize the two great eastern traditions of prayer, and in so doing he prepares the way for the later Byzantine Hesychast movement that would come after him. He is not merely a footstool for others, however, and his Hymns in particular, offer many aspects of robust and original insight which surpass his teachers and his sources, as only a man who speaks directly from experience can manage to do. The level and the passion of the direct "encounter" with Christ in the Hymns is unparalleled. Not least among Symeon's achievements is the immense emphasis he lays on the primacy of the experience of repentance (metanoia) in the highest levels of spiritual insight. For many of his predecessors penitence had been regarded as a preparatory step, a lowly stage of pro-paideusis on the way to mystical insight. For Symeon it is a spiritually advanced state that is the sole gateway of all human experience of God: and in this he is profoundly faithful to the Gospel tradition. He has been called "The Mystic of Fire and Light," ${ }_{3}$ but it would not be amiss to call him also: "The Mystic of Conversion and Love." Much of this doctrine is encapsulated in the Hymns, and it is to these we can now turn, so as to give something of their spirit and teaching.

\section{THE HYMNS OF DIVINE EROS}

There are a total of 58 Hymns in the authentic corpus, amounting almost to 11,000 verses. They are all written in liturgical style ${ }^{34}$ (probably with performance in mind not merely private reading) in a strongly pulsed rhythm that uses the metrical devices of either eight, ${ }^{35}$ twelve, ${ }^{36}$ or fifteen ${ }^{37}$ syllables to the line. Sometimes end rhymes and half-rhyme are used. Several have the poetic pulse that is comparable to Longfellow's epic Hiawatha, and they run into similar problems (for most are long) in sustaining the drive of the sense over against the soporific beat of the line: though in some cases the juxtaposition of the startling contents (visions, revelations, denunciations of enemies, and lurid confessions of sins), are exactly balanced by the mantra-like beat. No existing translation has attempted to render this either exactly or impressionistically so far. $^{38}$ Several of them are in the form of dramatic dialogue ${ }^{39}$ which advances the conception of the soul addressing the bridegroom as the beloved (a theme 
taken from the Canticle of Canticles, especially as that foundational text had been interpreted by the Greek Fathers such as Origen, and Gregory Nyssa).

The corpus of the Hymns opens with a marvellous and para-liturgical Epiclesis, or invocation, of the Holy Spirit, to inspire and energize the poems. It rolls off in 27 repetitions of the invocation Elthe, "Come!" and after that blossoms out into the significant liturgical phrase "Eucharisto soi." ${ }^{40}$ The hymns are thus meant as a priestly eucharistic celebration, and thus the mystic starts even at the outset to celebrate the soul's unitive mystery, its access to the divine presence by the grace of the Spirit:

Come true light / Come eternal life / Come hidden mystery /

Come nameless treasure. /

Come ineffable deed, / Come inconceivable person/ Come endless bliss, /

Come un-setting sun $/ \ldots$.

Come untarnishing crown / Come purple of our great King and God /

Come crystal belt studded with gems/ Come unapproachable sandal /

Come royal purple and right hand of the King /

Come you whom my poor soul has longed for, and longs for still ......

I give you thanks that you have become one single spirit with me. ${ }^{41}$

While it is true that the hymns are not liturgical compositions in the standard sense, they celebrate a para-liturgy of the ascent of the soul. And the beginning of the ascent, as Symeon emphasizes in this opening Epiclesis, is the descending gift of the Divine Spirit that consecrates the "mysteries" of the inner life of the disciple. It is this simple, but fundamental, principle that characterises the authentic channels of Christian spirituality and mysticism: that there is no path to God other than the path God has beaten towards us, through the economy of the revelation of the Trinity (and its high point of the encounter between flesh and spirit in the incarnation ${ }^{42}$ ), and through the purifying and consecratory action of the Spirit of God in the innermost recesses of human lives. ${ }^{43}$

In the Hymns Symeon is writing, generally, at a level of the most profound first-person intimacy. Even those several hymns which are clearly meant to be given to his disciples (where he speaks of the monastic virtues, and warns about the dangers of neglecting the spiritual elder's counsels) are couched in language that refers constantly to his own experience. This is "personal experience" taken to a pitch, and quite unlike anything that had yet appeared in Byzantine spiritual writing. It is the visions he has had of Christ's light, shining on his mind and casting him into ecstasy, visions that have changed his soul and filled him with a burning desire to communicate this "theology" as a confession of praise, that drive on his poetry. Some of the hymns are apologetic attacks on his enemies whom he knew were orchestrating his exile, but even these are turned into a discourse on the generic theme: that theology can only be experienced, not learned from hearsay (even from the most authoritative 
sources). Those sources themselves, the writings of the saints, only have authority because their authors had once experienced as true what they subsequently write about. In his day and age, as he never ceases to complain, it has become so standard a cry that the "time of experience" lies in the past of the Church, and will not return, that the false conclusion is even propounded as fact: men and women today can only imagine what the acts of God were like by reference to history and tradition. ${ }^{44}$ For Symeon this is the great heresy of his age. He shouts out in the Hymns that unless one has experienced directly, personally, in a "sensible" or perceived manner, the working of the Holy Spirit and, what's more, perceived it in a manner that leaves not the slightest doubt in the heart that it was the Holy Spirit of God who seized and changed the soul, then there can be no basis for claiming to be a Christian.

\footnotetext{
If you have not discerned that the eye of your mind has been opened, And that it has seen the light; If you have not perceived the sweetness of the Godhead; If you have not been personally enlightened by the Holy Spirit. . . . If you have not sensed that your heart has been cleansed And has shone with luminous reflections; If, contrary to all expectation, you have not discovered the Christ within yourself; If you have not been stupefied, at your vision of the divine beauty; And have not become oblivious of human nature When you saw yourself so totally transfigured.....

Then tell me-how is it that you dare to make any statement at all about God?45
}

This, of course, was fighting talk: as much then as it would be now. He immediately raised the hackles of many in the clergy who preached the virtue of a sober faith that avoided the "highs and lows" of felt experience. Some of them took such exception to Symeon that they mounted an argument against him on the grounds that if he kept on claiming to have "really experienced" God directly, then he was guilty of heresy, in so far as he had contradicted a basic element of Christian revelation, namely that God was unapproachable by essence and infinitely transcendent.

\section{A "STAMMERING THEOLOGY"}

It was to counter this argument that Symeon returns, throughout so many of his Hymns, to the central importance for the Christian life, of the concept of the "Economy of Salvation" (Oikonomia tes Soterias). The term in Patristic Greek meant the way God had worked so that human experience could be caught up in the mystery of Christ's incarnation (the apparently "contradictory" joining together of godhead and humanity in the seamless unity of the Christ). For Symeon the "Hypostatic Union" is the paradigm of how the soul can be authentically caught up in rapture, and experience God directly. To 


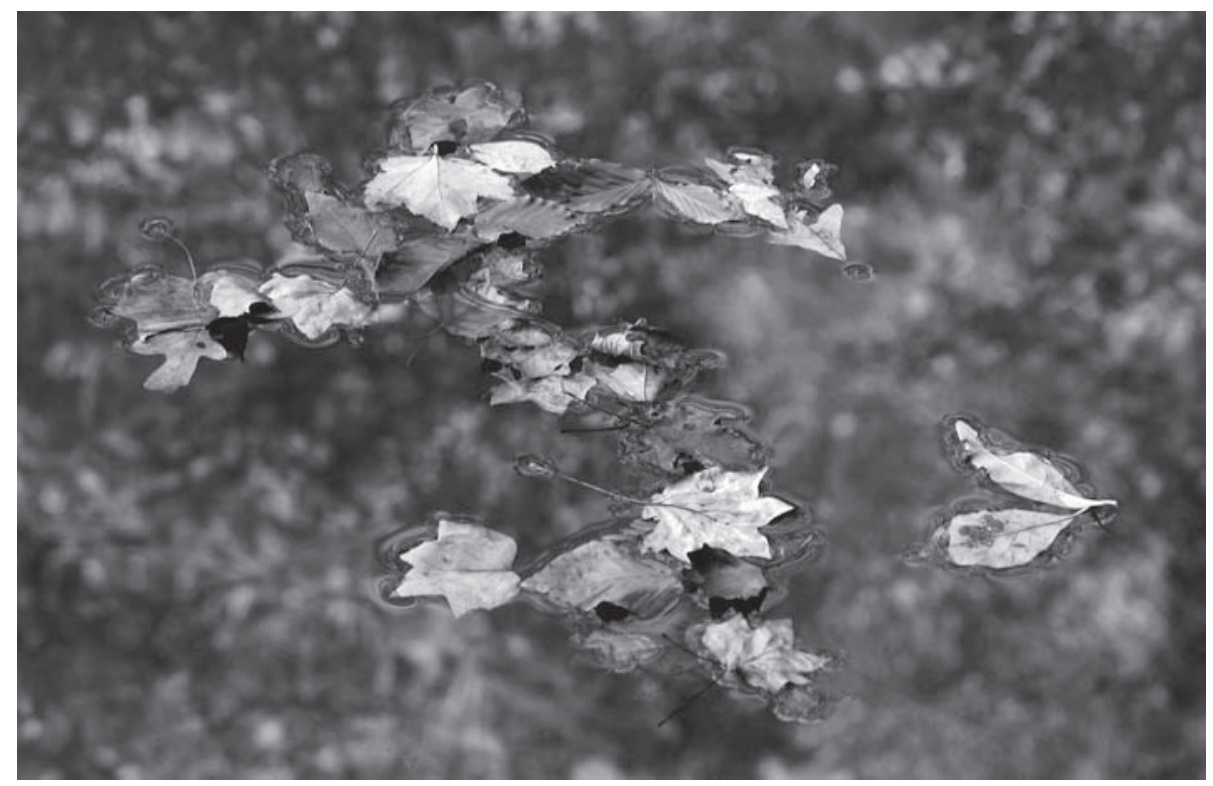

Self-Organized Grace. () Andy Ilachinski.

justify this, especially since it was highly controverted in his time by those who wanted to protect the transcendent unknowability of the divine, over and against claims of mystics they regarded as cranks, Symeon tries to elaborate, from his experience of the encounter, just how it is that his soul entered into communion with the divine. These are passages of "stammering theology" as he tries to express the experience in convincing metaphors. Time and again he ends by saying that the task is hopeless. Unless one has experienced it oneself the words will sound confused and meaningless: although those who have known it themselves will recognise immediately that this is the heart of the experience of all the saints. The feeble experience of the little soul that senses God's light, however, is not to be despised: a sensation of the fraction of the divine light is nonetheless an experience of the entire and luminous divinityand in that paradoxical meeting God is known perfectly to the creature even if He cannot be comprehended:

What is this awesome mystery that is taking place within me?

I can find no words to express it:

My poor hand is unable to capture it,

In describing the praise and glory that belong

To the One who is above all praise,

And who transcends every word...

My intellect sees what has happened,

But it cannot explain it;

It can see, and wishes to explain,

But can find no word that suffices,

For what it sees is invisible and entirely formless, 
Simple, completely uncompounded,

Unbounded in its awesome greatness.

What I have seen is the totality recapitulated as One,

Received not in essence but by participation.

It is just as if you lit a flame from a live flame:

It is the entire flame you receive. ${ }^{46}$

Symeon's form of apophaticism (the doctrine that the ways of God cannot be spoken of in the words of earth) is not so much a formal doctrine, as a rhetorically crafted "stuttering" to articulate an experience he cannot describe. At times he almost gives up on his readers :

What point is there in trying to explain all of this to you, Or trying to make you understand it all?

If you yourself have not felt it by personal experience,

You will be unable to know it. ${ }^{47}$

And yet it is clear that Symeon, throughout the Hymns, is calling to all his readers to experience the mystical presence, not merely to an élite. The experience of the divine is initiated by a wholehearted response to God. It does not require great intelligence, or years of asceticism. It requires only readiness. The distinctive element in Symeon's spiritual initiation, therefore, is the great stress he places on the position of repentance as a gateway of mystical vision. ${ }^{48}$

In many spiritual systems of the previous (and later) teachers, the ascent of the soul was envisaged as a three-fold progress: first one repents and begins the painful purification process where the soul withdraws from a crass and external life, to a more disciplined ethical and studious condition. Secondly one learns to pray more and with greater attention and devotion, often sensing the growing the warmth of the Love of God encircling the soul and a deepening understanding of God. Thirdly, after years of faithful attachment to the spiritual paths and their deepening mysteries, one finally attains to the highest stage of the spiritual life, the Unitive. It is at this third level alone that the word mystical properly applies. The threefold ascent was given various labels: praxis, theoria, gnosis, or in the West: purgative, illuminative, unitive, more or less based on the taxonomy established by the great fourth century spiritual writer Evagrius of Pontus, and underlined by the sixth century theologian Dionysius the Areopagite.

Symeon knows their writings, and their theory, but himself sings a different song. As far as he knows, the great wonder of the mystical illumination is that it is given by Christ to chosen disciples to call them out of darkness and into the fire of love. For him the great illumination was first given when he was in the depths of sin, and wandering in error. Not given as a reward to a soul that had shown itself ready and faithful, but given to one that was 
evidently unworthy, it served as the great spur of conversion of life (metanoia). It was given without preceding merit, and continued on the grounds of love alone. Symeon's great contribution to Christian spirituality, therefore, is how the incomprehensibility of God is defended not by insisting on God's inscrutable absence from the earthly creation, but by celebrating the manner in which an incomprehensibly deep mercy reaches into the heart of alienation and returns the human soul to its correct purposes: the vision of the Creator. For Symeon, the sinner becomes at the moment of conversion the recipient of God's deifying mercy:

I was in the world like a blind man,

Like an atheist ignorant of my God,

But you yourself had pity on me

And turned me back to yourself.

You caused your light to shine

So brightly in my darkness

And summoned me back to you my Maker. ${ }^{49}$

This is not merely a topos that God will always seek to convert us, but a specific sense that God raptured him, from sinner to saint, in the act of making his divine light radiate through the soul of the mystic. At that eschatological moment, the chasm between God and creature, between flesh and spirit, was abolished even in this present kairos, and that ecstatic moment is extended in the sacramental life of the Church, where eucharistic communion celebrates the same mystery of the metaphysical transfiguration which is the communion of love:

By what boundless mercy, my Savior,

Have you allowed me to become a member of your body?

$\mathrm{Me}$, the unclean, the defiled, the prodigal.

How is it that you have clothed me

With the brilliant garment,

Radiant with the splendor of immortality,

That turns all my members into light?

Your body, immaculate and divine,

Is all radiant with the fire of your divinity,

With which it is ineffably joined and combined.

This is the gift you have given me, my God:

That this mortal and shabby frame

Has become One with your immaculate body

And that my blood has been mingled with your blood.

I sense too that here I have been made one with your divinity,

And have even become your own most pure body:

A brilliant member lucidly transparent,

Luminous and holy. 
I see the beauty of it all, I can gaze upon your radiance.

I have become a reflection of the light of your grace. ${ }^{50}$

Only in such an intense union, Symeon argues, as people have often dreamed of but usually set into future horizons or ascribed as something "for others" or "for saints long ago," will the meaning of each human life be revealed and given. Symeon constantly refutes the deadening notion that spiritual union with God is not for every Christian, and not for the here-and-now:

Do not say that without His presence it is possible to be saved.

Do not say that one can possess the Spirit

Even if one is not consciously aware of it.

Do not say that God cannot be seen by human beings.

Do not say that humans may never see the light of God;

Or at least that it is not possible for this generation.

My friends this is never impossible.

It is more than possible-for those who desire it. ${ }^{51}$

\section{THEOSIS: ECSTATIC KNOWLEDGE OF THE LOVE OF GOD}

The love of God, in the hands of this extraordinary teacher, is meant to be ecstatically known in the life of each and every soul making the earthly pilgrimage. For Symeon that entire pilgrimage is only rendered meaningful if we understand that human beings are in process of a radical spiritualization, where their faculties are constantly refined (such as happens in our educational processes) and from being predominantly material beings, wrapped up in the instincts and aspirations of an animal existence, we progress to become the sacramentally embodied visionaries of God, destined to live predominantly in the radiant luminosity of the Next Age were we shall finally be made "like gods" in glory. Symeon here develops the tradition Greek patristic teaching on the Economy of salvation considered as the Deification (Theosis) of the human race. It is, as Symeon implies, possible for a human consciousness to enter into the authentic presence of the deity on earth, in so far as that condition, and possibility, has first been demonstrated and presented to the church in the mystery of the incarnate economy of the God-Man. Theosis, however, is not a "Next Age" phenomenon, but the essence of the spiritual life on earth as it ought to be lived. The ineffable knowledge of the illumined mystic is thus at one with the abiding presence of the deity within:

God heard my cries

And from unimaginable heights he stooped down

And looked upon me.

Once more he had pity on me and allowed me to see

The One who was invisible to all, 
A much as human kind can bear.

Seeing him I was astounded,

Me who was locked up in my tiny house of bone,

All surrounded by darkness ...

I saw him in the midst of my tiny house,

So quickly had he entered in, complete,

Uniting himself to me inexpressibly

Joining himself to me inexpressibly

Suffusing himself in me unconfusedly,

Just as fire can permeate iron,

Or light shine through crystal.

So it was he made me become like fire itself;

Revealing himself to me as Light. ${ }^{52}$

Like many Christian spiritual masters Symeon is greatly influenced by the imagery of the Canticle of Canticles, especially as that book had been given a macro exegesis by Origen in his Commentary on Canticles. There, Origen had interpreted the image of the lovers running through the garden at night, seeking one another in the perfumed orchard, as a symbolic narrative of the soul in its driven quest for the love of the divine Logos. Symeon takes the intimacy of the encounter to new heights. The passion of the meeting is so often linked to his experience of the forgiveness of God, and the sensation of the luminous mercy, that the dazzling encounter with God's light is even described as something that startles the soul and makes it wish to run away from the divine presence and lose itself in the familiarities of the flesh:

I see the unseeable beauty,

That unapproachable light, that unbearable glory.

My mind is completely astounded.

I tremble with fear...

I found Him whom I had seen from afar,

The One Stephen saw when the heavens opened,

And later whose vision blinded Paul.

Indeed he was a fire in the center of my heart.

I was outside myself. I broke down, lost to myself,

And unable to bear the unendurable brightness of that glory.

And so, I turned,

And fled into the night of the senses. ${ }^{53}$

Or again:

Love came down, as is its way,

In the appearance of a luminous cloud.

I saw it fasten on me and settle on my head.

And it made me cry out, for I was so afraid;

Thus it flew away, and left me alone. 
Then how ardently I searched after it;

And suddenly, completely,

I was conscious of it present in my heart,

Like a heavenly body.

I saw it like the disc of the sun ...

It closed me off from the visible,

And joined me to invisible things.

It gave me the grace to see the Uncreated. ${ }^{54}$

Symeon's choice of hymnic genre to express this mystery of union, is not the liturgical Kontakia of the previous writers such as John Damascene and Romanos Melodos, rather the strikingly secular concept of Erotikai, or "Love Songs." The equivalent today for a theologian would be to compose explicit rap lyrics about the nature of divine love; and many in his time found this highly objectionable.

Part of his intent was to speak about the "impassibility" (apatheia) that is the state of soul of the saint who arrives at such a degree of love for God that

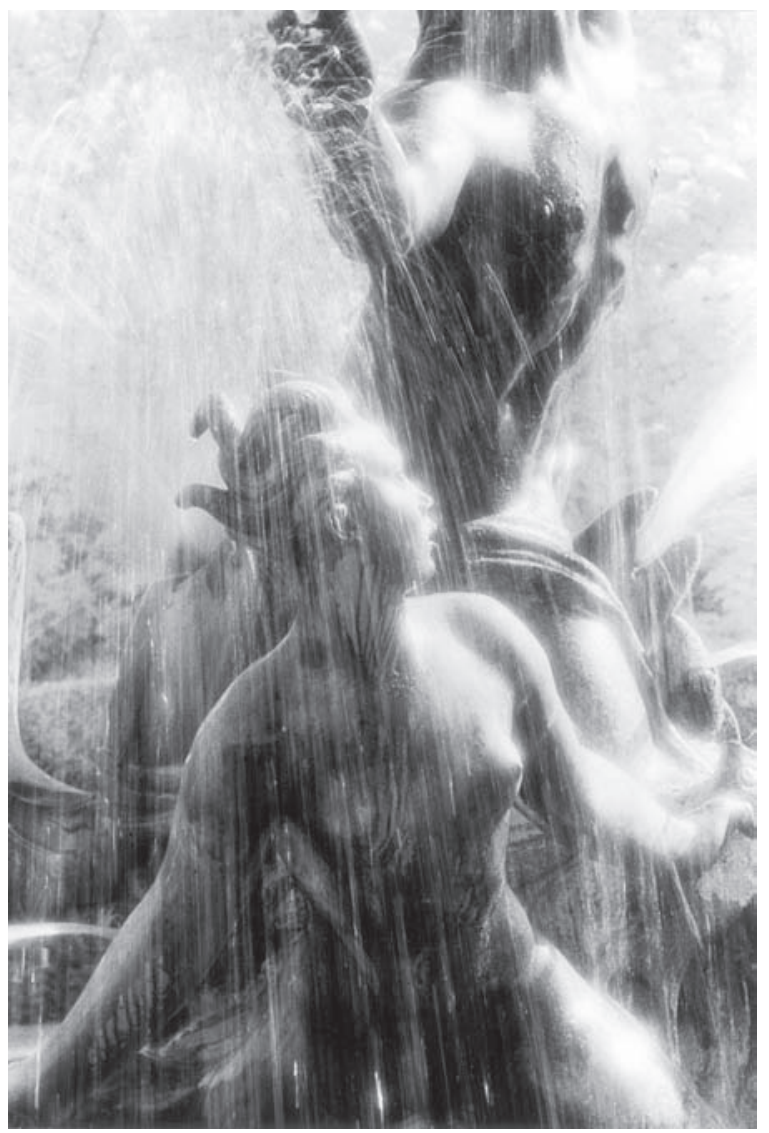

Regents Park, London. ㅇ Derek Langley. 
earthly affairs and sensual distractions can no longer affect him. This was an old and traditional doctrine among the eastern monks, mainly sustaining the point that ascetical discipline and long training in prayer and fasting, can make the Christian disciple less vulnerable to temptations that would be significant for a beginner; simply because their fire of love and faithfulness renders such old temptations (sensuality, or decadence, or self-seeking) no longer attractive to them in any way. Symeon is quite unique, however, in pressing the notion of apatheia, so as to express it in terms of erotic passion. He tells his reader a few times not to understand him in a salacious sense, but it is clear that his intent is to shock (a deliberate rhetorical juxtaposition of apparent opposites), for he speaks lovingly of the manner in which all the saint's bodily members are transfigured in the light of Christ's glory: fingers, eyes, face all become luminous. And as he makes his list we come to the end: "Even this penis becomes like Christ." ${ }^{55}$ The next half-line, of course, gives his (rhetorical) game away: "And you, reader-are you shocked at this?" On many occasions in the Hymns, Symeon speaks of the soul in vox feminina, as raptured and ravished by the love of its beloved. His imagery presses the erotics of the ancient theme of "Christ's bridal chamber" to the limit. It will not be a theme that is common among the Christians until the female mystics of the Medieval West take up the idea several centuries after him. Was it, perhaps, something related to Symeon's unique familial and psychological make-up as a Byzantine eunuch, or his relatively late and "emergency" entry into monastic discipline that allowed this rhapsodic theme to emerge so early, and so passionately, in his works?

Symeon was a unique and forceful character; and few have ever written in comparable ways about the love of God. Similarly, few theologians have ever called out to the ordinary Christian to embrace the heights of union with God in a deifying light. His uniqueness as a theologian has often been described in terms of his unusual visions, and ecstatic experiences. For me, however, his real uniqueness is the manner in which he juxtaposes the infinite pity and condescension of God with the plight of the sinful creature. The heights of the spiritual life, as Symeon envisages them, are the very inner workings of the path of salvation. Our salvation is synonymous with our theosis, or deification in light, even as we live here on earth. Deification is not, therefore, a prize for the righteous, once they have been purified, but is rather the fundamental grace of the Holy Spirit which is offered to all, to effect their mystical transfiguration into Christ's very members.

His challenge is that if we have not achieved this exalted state as yet, it is not for want of God's trying to communicate it to us. If we have not yet entered into the light: only the heart on our side can be wanting, since the divine gift and promise (the Holy Spirit) is already there. The "sting in the tale" in his message, is that if we have not yet experienced the heights of the 
glory, then we have not yet even started. It was radical doctrine like this, put across so rhapsodically in his genre of popular verse (the love song), that got Symeon into such levels of trouble in his own day with the religious bourgeoisie. It is a message that is still dramatically shocking over a millennium later.

\section{A PILGRIMAGE INTO COMMUNION}

Symeon's legacy ran on into the later thirteenth and fourteenth centuries on Mount Athos, where he seemed like an early champion for the Hesychast movement. When that spiritual tradition (with its distinctive themes of the repetition of the Jesus Prayer, ${ }^{56}$ the emphasis on the vision of the divine light of Thabor, and the veracity of mystical claims to have experienced God "in the earthly condition") encountered Symeon's writings it thought it recognised itself in the songs of the earlier writer. So it was, before too long, that Symeon became the pseudonymous "father" of the short, but very famous, Athonite tract describing how the Jesus Prayer ought to be conducted. The treatise On the Three Methods of Prayer kept his name and memory alive on Mount Athos, but fundamentally subjected his impact to that of the more famous Hesychast theologians such as Gregory Palamas or Gregory of Sinai; that anachronistic reading of his work obscured no small part of Symeon's own theology, not least his extraordinary stress on repentance and the possibility of the sinner to be lifted up into intimacy of God, as a dramatic demonstration that mystical perception was not earned by fidelity (though it ought to be prepared for by discipline) but was rather an entirely graceful gift from the God of all grace.

In many respects Symeon was authentically a forefather of the Hesychast movement, but more so than they, was inspired by deeper and older traditions he had learned from the Syrians, especially Pseudo Macarius, Mar Isaac, and Pseudo Dionysius, that the heart of the disciple was the preferred dwelling place of the Spirit of God, who would constantly seek to make the divine temple radiant with the ineffable presence. In short, for Symeon, the so-called secular life, or even the life of sin that closed the eye of spiritual awareness, was an unnatural contradiction of the inner and essential nature of a Christian. Deification, on the other hand, was the natural condition for such a soul, caught up into the great mystery of the incarnation of the Logos. To that extent, the irradiated mind and the luminous heart, were not extraordinary things: rather it was extraordinary that they had been so forgotten and were so rarely manifested among the body of disciples.

Symeon's rapturous song in the Hymns of Divine Eros about the glories of mystical perception, for all its own extraordinary character, is fundamentally trying to remind his readers of that startling yet simple truth: that the deified soul is to the present world like a fiery Sun, whose radiance cannot be con- 
tained. Truth will out, one way or another. The disciple is either illumined or not illumined. The difference is one between darkness and daytime; and the rebuttal of our own illusions about our spiritual status is the necessary first step to the divine encounter. And yet the systemic change Symeon is calling for here is profoundly difficult to negotiate, given our own addictions to techniques of avoidance (our convenient deafness and blindness when it comes to issues of metanoia) as well as the ever-present support that so many societal and ecclesial structures of delusionality can give to the state of quiescence. Sensitive of the need for an "elder," and a guide, to help the believer stand up and move, Symeon sings a song that is predominantly one of encouragement, despite all his warnings and exhortations. Even to his contemporary readers he serves as a "spiritual father." His message, at once deeply embedded within the structures of the Church, yet simultaneously on the prophetic margins, has much to teach us, especially in a day when living elders seem so few and far between. Symeon shouts out for the need to change; yet he also prioritizes for his readers the joys of this journey that will become a pilgrimage into communion.

\section{NOTES}

1. Active mainly in Constantinople, he was called the "new" theologian derisively by his enemies, to suggest that he was an innovator, but it was taken up by his supporters as an affirmation that he was a new "Theologian" par excellence, like John the Theologian (the 4th Evangelist) or Gregory the Theologian (St. Gregory of Nazianzus) two of the greatest theologians of the Eastern Christian tradition. The critical edition of the Hymns, with French translation, is the three-volume version by J. Koder, Syméon le Nouveau Théologien: Hymnes, Sources Chrétiennes 156, 174, 196 (Paris: Éditions du Cerf, 1969, 1971, 1973): 22. There is one English version: G. Maloney, trans. The Hymns of Divine Love (New Jersey: Dimension Press, 1975 \& 1999). All English translations in this essay are my own.

2. More literally the "Erotics of Divine Hymns" or "Impassioned Love Songs for God." The title is often woodenly translated as "Hymns of Divine Love," presumably to avoid the "scandal" (which Symeon definitely intended) of attributing the notion of erotic desire to the monk's relation to the deity. The title is meant to evoke the Erotikoi Hymnoi of Hierotheos, whom Dionysius speaks of as his mystical teacher in Divine Names 3.2. Koder describes in more detail the literary connections Niketas makes between Symeon and Dionysius in the Preface he composed for his edition of Symeon's Hymns. See Sources Chrétiennes 156 (1969): 53-64.

3. His own writings give several autobiographical reminiscences, which are supplemented by a Vita composed by the Abbot of Stoudium monastery, Niketas Stethatos, about thirty years after Symeon's death. See I. Hausherr, ed., and P. G. Horn, trans., "Un grand mystique byzantin: Vie de Syméon le Nouveau Théologien par Nicetas Stethatos," Orientalia Christiana 45 (1928). (Hereafter cited as Vita, with section followed by page number. Hymns will be cited with hymn number followed by verse number).

4. His eventual rank of Spathocubiculary (Gentleman Sword-Bearer of the Imperial Bedchamber) was originally a position reserved for eunuchs, though by Symeon's day such offices were merely ceremonial, and did not have the same requirements. Stethatos, however, had contact with the original disciples of Symeon, several of whom he used as 
sources in his Vita, especially the monk Theodoulos who was Symeon's original copyist as a young boy. Vita 130-131: 189 .

5. Hymn 20.98. Maloney, Hymns of Divine Love, 91.

6. Hymn 56. 9. Maloney, Hymns of Divine Love, 285.

7. Niketas, the biographer, says elliptically that: "he was ushered out of life in no ordinary manner."

8. He often hints, throughout his writings, at a somewhat dissolute life (younger Byzantine eunuchs were often regarded askance by the general populace), and later in his Hymns he confesses to having committed all manner of sins (enumerating them in a lurid list and insisting he is being serious-Hymns 24-25). Commentators have often taken this as a topos, a sign of humility, accusing himself of every sexual license possible, but Symeon himself seems to have no illusions about his earlier life, and places such emphasis on the virtue of repentance that we should take him more seriously than presuming he was the innocent youth of the pious biography.

9. Known as Symeon the Elder, or Symeon the Pious (Eulabes).

10. In the Vita, 23: 32, we are told how, in a vision of light, he heard Christ himself describe Symeon Eulabes as: "Apostle and disciple of Christ, mediator and an ambassador [for the people] with God."

11. P. (=J. A.) McGuckin, trans. Symeon the New Theologian: Chapters and Discourses (Kalamazoo: Cistercian, 1982), 3.4: 73.

12. In the sense of "perceived" or "felt" (aisthetos), a concept which is basic to his understanding of true Christianity as distinct from "wishful" or theoretical Christianity. Theological and Practical Chapters 3.47: 85. Symeon argues that if the Christian has not already "felt" the abiding grace of the Spirit in one's lifetime, one has little ground to hope in the vision of God after death.

13. Namely, Symeon of Ephesus, and Meletios. Vita, 33: 44.

14. Vita, 30: 42 .

15. Vita, 19: 28. For a fuller discussion of the visions of light and the role they play in his autobiographic accounts, his biography, and in his theology, see: J. A. McGuckin, "The Notion of Luminous Vision in 11th Century Byzantium: Interpreting the Biblical and Theological Paradigms of St. Symeon the New Theologian," ed. M. Mullett, Work \& Worship at the Theotokos Evergetis (Belfast: Queens University Press, 1997), 90-123.

16. J. A. McGuckin, "St. Symeon the New Theologian and Byzantine Monasticism," ed. A. Bryer, Mount Athos \& Byzantine Monasticism (Aldershot, Variorum Press, 1996), 1735 .

17. It is written thirty years after the death of the saint, based on several "presuppositions" of his own, as well as on personal reminiscences from Symeon's disciples Arsenios (Vita, 45: 58), Symeon of Ephesus and Meletios (Vita, 33: 44).

18. Vita, 22-23: 32 .

19. The "rule" observed at the St. Mamas monastery.

20. St. Symeon the New Theologian: the Catechetical Discourses, trans. C. J. De Cantazaro (New York: Paulist Press, 1980).

21. Powerful and rich men such as the Patrician Genesios. Vita, 54-55: 70-71.

22. Vita. $38-39$, pp. 50-52.

23. Niketas' list of Patriarchs is not too sure: the issues of the chronology have been discussed, illuminatingly, by Hausherr in his introduction to the Vita., and by V. Grumel, "Nicholas II Chrysoberges et la chronologie de la vie de S. Syméon le Nouveau Théologien," Revue des études byzantines 22 (1964): 253.

24. He was asked the seemingly "innocent" question: were the trinitarian hypostases to be "really" or simply "notionally" distinguished. It would be possible (for a hostile inquisitor) to lay heresy charges for a reply asserting either position.

25. Especially in Hymns 21, 52, and 58. 
26. See especially St. Gregory of Nazianzen (Oration 27) whose thought Symeon often reproduces.

27. The aristocrat Christopher Phagouras provided funds, along with the Senator Genesios and several other wealthy Constantinopolitans who remained loyal to Symeon's cause, and circle. See Vita, 102: 140; 104: 142; 109: 152.

28. The first collection had been prepared by Symeon himself in his late old age. Vita, 131: 188.

29. Including small additions of his own, and some "commentary." The titles for each Hymn (often not helpful) were supplied by one Alexis the Philosopher, possibly a collaborator of Niketas. See Koder, Sources Chrétiennes 156:22.

30. Though, ironically, it was not written by him at all. The text entitled The Three Methods of Prayer can be found in The Philokalia vol. 4, trans. G. Palmer, P. Sherrard, and K. Ware (London: Faber \& Faber, 1995): 64-75.

31. The primary texts now available in English are as follows: C. J. De Catanzaro, trans., Symeon the New Theologian; a translation of "The Ethical Discourses" and biography in: A. Golitzin, St. Symeon the New Theologian. 3 vols. (New York: St. Vladimir's Seminary Press, 1995-1997); P. (J. A.) McGuckin, Symeon the New Theologian; Maloney, The Hymns of Divine Love; G. Palmer et.al., Philokalia vol. 4, 11-75.

32. Recent scholarly studies include: H. Alfeyev, St. Symeon the New Theologian and Orthodox Tradition (Oxford: Oxford University Press, 2000); B. Krivocheine, In the Light of Christ (New York: St. Vladimir's Seminary Press, 1987); J. A. McGuckin, "St. Symeon the New Theologian and Byzantine Monasticism," 17-35; J. A. McGuckin, "St. Symeon the New Theologian (d. 1022): Byzantine Theological Renewal in Search of a Precedent," ed. R. N. Swanson, The Church Retrospective: Studies in Church History 33 (Oxford: Boydell \& Brewer, 1997); J. A. McGuckin, "The Notion of Luminous Vision in 11th Century Byzantium,” 90-123; G. Maloney, The Mystic of Fire and Light (New Jersey: Denville, 1975); J. Pelikan, "The Last Flowering of Byzantium: The Mystic as New Theologian," ch. 6 in: The Spirit of Eastern Christendom (Chicago: University of Chicago Press, 1974 \& 1977); H. J. M. Turner, St. Symeon the New Theologian and Spiritual Fatherhood (Leiden: Brill Academic Publishers, 1990).

33. By Niketas Stethatos, in the Vita. 27. p. 38.

34. He is aware of the great Byzantine liturgical poets before him, Gregory of Nazianzus, Romanos the Melodist, John Damascene, and Joseph the Hymnographer.

35. 8 hymns out of the 58 , several of which are irregular: $6,17,23,29,30,35,44,53$.

36. 14 hymns: $2-5,9-10,20-21,24,37,39,50,57-58$.

37. The so-called "political" verse of Byzantium. It is Symeon's preferred metre used in 36 hymns: $1,7-8,11-16,18-19,22,25-28,31-34,36,38,40-43,45-49,51-52,54-56$.

38. Although there is a good attempt in the Holy Transfiguration Press version of the (apocryphal) Hymn before Communion which adopts a seven syllabic line. A few verses will give the effect: "I have sinned more than the harlot / Who on learning of thy lodging / Went and purchased myrrh most precious / And with boldness she approached Thee / To anoint Thy feet and lave them ... " Service of Preparation for Holy Communion. (Boston: Holy Transfiguration Orthodox Monastery, 1986), 58. (No author/ editor cited).

39. See Hymns 15, 17, 18, 22, 23, 53, 58.

40. The Eucharistic preface: "We give you thanks, we give you praise." Symeon deliberately sets his hymns in a eucharistic context, in which the praise of the mystic is comparable to the liturgical offering of mysteries, rendered sacred by the operation and descent of the Holy Spirit at the epiclesis.

41. Preface to the Hymns: "The Mystical Prayer of Our Father Saint Symeon," trans. Koder, Sources Chrétiennes 156: 150, 152.

42. See especially Hymns 20, 32, and 36. 
43. See, for example, Hymn 15.

44. Such as Hymns 1, or 21.

45. Hymn 21. 160f. Koder, Sources Chrétiennes 174: 143.

46. Hymn 1. Koder, Sources Chrétiennes 156: 157-158.

47. Hymn 23. Koder, Sources Chrétiennes 174: 223.

48. Such as Hymns $1,7,11,13,14,17,24,37$, and 41 as chief among many others.

49. Hymn 37. 16-22. Koder, Sources Chrétiennes 174: 460.

50. Hymn 2. Koder, Sources Chrétiennes 156: 178.

51. Hymn 27. Koder, Sources Chrétiennes 174: 288.

52. Hymn 34. Koder, Sources Chrétiennes 174: 366-370.

53. Hymn 11. Koder, Sources Chrétiennes 156: 238.

54. Hymn 17. Koder, Sources Chrétiennes 174: 41.

55. "All our members become Christ himself - Can you not see Christ even in this penis?"Hymn 15. 161. Koder, Sources Chrétiennes 156: 290. A eunuch rhetorician could, of course, discourse on the notions of apatheia demonstrated in the sexual organs, in a way others could not so readily accomplish, and yet still move on from that point, to his central argument that love of God is the passion that apatheia seeks to stimulate.

56. Not explicitly to the fore in Symeon but alluded to in his constant personal petitions for the mercy of Jesus. 